\title{
Altered distribution of NK cell subsets in children with Mycoplasma
}

\section{pneumoniae pneumonia}

\author{
Authors: Dan-Dan Zhang ${ }^{1 \dagger}$, Xiu-Ling Cao ${ }^{2 \dagger}$, Yu-Qin Li ${ }^{2}$, Ying Ding ${ }^{2}$,Yu-Jie Fan ${ }^{2}$, \\ Yi-Xue $\mathrm{Yu}^{2}$, Yan $\mathrm{Li}^{2}$, Wei-Fang $\mathrm{Zhou}^{2 *}$ and $\mathrm{Chu} \mathrm{Chu}^{2 *}$. \\ ${ }^{\dagger}$ Dan-Dan Zhang and Xiu-Ling Cao contributed equally to this work. \\ *Corresponding author: zwf_1969@163.com, szdxchuchu@163.com
}

\begin{abstract}
Background: Mycoplasma pneumoniae pneumonia (MPP) is a common respiratory illness in children, particularly those with allergic constitutions. NK cells and cytokines are thought to be involved; however, understanding of the immunopathology of MPP is incomplete.

Methods: Peripheral blood samples were collected from 51 children hospitalized with with MPP, 26 with an allergic constitution and 25 without, and 29 healthy controls. NK cell subsets were analyzed by flow cytometry and the expression of interleukin (IL)-1 alpha and IL-18 was detected by ELISA. The relationship between NK cell subsets and the expression of IL-18 and IL-1 alpha was determined.

Results: The number of $\mathrm{CD} 3^{-} \mathrm{CD} 56^{+} \mathrm{NK}$ cells and $\mathrm{CD} 3^{-} \mathrm{CD} 56^{\mathrm{dim}} \mathrm{CD} 16^{\text {bright }} \mathrm{NK}$ cells in children with MPP was lower than in healthy controls $(\mathrm{P}<0.05)$. The percentage of $\mathrm{CD}^{-} \mathrm{CD} 56^{+} \mathrm{NK}$ cells, $\mathrm{CD} 3^{-} \mathrm{CD} 56^{\mathrm{dim}} \mathrm{CD} 16^{\text {bright }} \mathrm{NK}$ cells and the number of $\mathrm{CD}{ }^{-} \mathrm{CD} 56^{\mathrm{dim}} \mathrm{CD} 16^{\text {bright }} \mathrm{NK}$ cells in the MPP allergic group were lower than in the non-allergic group $(\mathrm{P}<0.05)$. The expression of IL-18 was significantly increased in the MPP groups $(\mathrm{P}<0.05)$, and the absolute number of $\mathrm{CD} 3{ }^{-} \mathrm{CD} 56^{\mathrm{dim}} \mathrm{CD} 16^{\text {bright }} \mathrm{NK}$ cells negatively correlated with IL-18 levels in the peripheral blood $(\mathrm{P}<0.05)$.

Conclusion: Reduced numbers of NK cell subsets were identified in children with MPP and MPP with an allergic predisposition compared with healthy controls. Concomitant increases in IL-18 in children with MPP suggest the involvement of IL-18 in the immunopathogenesis of MPP and may be related to the reduced
\end{abstract}


CD $3^{-} \mathrm{CD} 56^{\text {dim }} \mathrm{CD} 16^{\text {bright }} \mathrm{NK}$ cells.

Keywords: Mycoplasma pneumoniae pneumonia; allergic constitution; NK cell subsets; IL-18; IL-1 $\alpha$

\section{Background}

Mycoplasma pneumoniae (MP) is a common pathogen associated with community-acquired pneumonia in children. It can cause wheezing, asthma attacks, and aggravation of pneumonia in children[1]. An allergic constitution refers to the abnormal increase of antigen-specific IgE and allergic inflammation of target organs such as the respiratory tract, gastrointestinal tract or skin after exposure to allergens. It is a complex immune disorder characterized by the infiltration of eosinophils and the production of cytokines due to the differentiation of Th2 cells. MP infection is an important factor leading to Th2 cell inflammatory responses in children with allergic constitutions, and induces airway hyper-responsiveness[2]. NK cells are an integral part of the innate immune system and can act as a bridge connecting innate and acquired immunity[3]. NK cells are divided into $\mathrm{CD} 56^{\mathrm{dim}} \mathrm{CD} 16^{\text {bright }}$ and CD56 ${ }^{\text {bright }} \mathrm{CD} 16^{\mathrm{dim}}$ subsets. In this study, we analyzed the distribution of NK cell subsets and cytokine levels in the blood of children with Mycoplasma pneumoniae pneumonia (MPP) and MPP with an allergic constitution to further understand the immunopathogenesis of MPP.

\section{Methods}

\section{Objects of study}

From March 2017 to January 2018, 51 children with MPP were hospitalized in the Children's Hospital Affiliated to Suzhou University. The patients included 26 in the allergic group and 25 in the non-allergic group. Twenty-nine healthy children in the same period were included as the healthy control group. 


\section{Selection criteria:}

MPP standard [4,5]: 1) pneumonia standard: respiratory symptoms, with or without fever, X-ray showed substantial lung infiltration; 2) Mycoplasma pneumoniae infection standard: nasopharynx aspirate (NPA) or bronchoalveolar lavage fluid (BALF) in MP-DNA-PCR. $>1.0 \times 10^{3}$ copies $/ \mathrm{ml}$; single serum MP-IgM $(>1.1 \mathrm{~S} / \mathrm{CO})$, double serum IgG and/or IgM increased 4 times or more than the first (7-14 days apart) and were diagnosed as acute Mycoplasma infection.

Any of the following criteria was defined as an allergic constitution[6]: 1) Clinical diagnosis of asthma, eczema, allergic rhinitis or atopic dermatitis; 2) History of drug or food allergy; 3) Blood allergen test or skin prick test had more than two positive allergens. Exclusion criteria: No asthma, eczema, allergic rhinitis or atopic dermatitis, no history of drug or food allergy, blood allergen test or skin prick test were negative.

\section{Experimental methods}

Within 2 hours of admission, $4 \mathrm{ml}$ of venous blood was collected and $2 \mathrm{ml}$ of whole blood was immediately analyzed by flow cytometry. Whole blood (2 ml) was collected in an anticoagulant tube and centrifuged for 5 minutes at $3500 \mathrm{rpm}$. The plasma obtained was stored at $-80^{\circ} \mathrm{C}$. 1) The percentage and absolute value of $\mathrm{CD}^{-}{ }^{-} \mathrm{CD} 56^{+} \mathrm{NK}$ cells and $\mathrm{CD}^{-} \mathrm{CD} 56^{\mathrm{dim}} \mathrm{CD} 16^{\text {bright }} \mathrm{NK}$ cells and $\mathrm{CD}^{-} \mathrm{CD} 56^{\text {bright }} \mathrm{CD} 16^{\mathrm{dim}} \mathrm{NK}$ cells in the lymphocyte population were detected by flow cytometry; 2) The plasma cytokines interleukin (IL)-18 and IL-1 $\alpha$ were measured by ELISA.

\section{Statistical methods}

Statistical data were analyzed using SPSS 21.0 software package. Normal distribution measurements were expressed as mean \pm standard deviation $(\bar{x} \pm \mathrm{s})$. T-tests were used for comparisons between groups. The measurement data of non-normal distribution were expressed as median (quartile spacing). Rank sum tests were used for comparison between the two groups. The counting data were expressed by ratio, and the comparison between groups was performed by Chi-square test or Fisher's exact probability method. The difference was deemed statistically significant when $\mathrm{P}$ 
$<0.05$.

\section{Results}

\section{Patient information}

The 51 children with MPP included 25 males and 26 females and the 29 healthy controls comprised 16 males and 13 females. There was no significant difference between the two groups. The average age of the children in the MPP group was $3.34 \pm 2.28$ years, and the healthy control group was $3.29 \pm 2.17$ years. There was no significant difference in age between the two groups $(\mathrm{P}>0.05)$. See Table 1

Among the children with MPP, there were 26 cases in the allergic group, 13 males and 13 females, and 25 cases in the non-allergic group, 12 males and 13 females. There was no significant difference between the two groups. The average age of the allergic group was $3.26 \pm 2.19$ and the non-allergic group was $3.43 \pm 2.40$. There was no significant difference in age between the two groups $(\mathrm{P}>0.05)$. See Table 1.

\section{Distribution of NK cell subsets in the peripheral blood}

Flow cytometry was used to detect NK cells and differentiate the subsets in the peripheral blood. The basic morphological differences of different cell groups were distinguished by scattering light signals, and then the lymphocyte groups were selected (Fig. 1A). NK cells were identified using basic morphological information, followed by positive expression of CD45, the common leukocyte antigen, and negative expression of CD3 (Fig. 1B) . In Fig. 1C, NK cell subsets were differentiated based on the expression of CD56 and CD16.

\section{Distribution of NK cell subsets in peripheral blood of children with Mycoplasma pneumoniae pneumonia}

The absolute value of $\mathrm{CD}^{-} \mathrm{CD} 56^{+} \mathrm{NK}$ cells in peripheral blood lymphocyte group of MPP group was $0.27(0.14-0.40) \times 10^{9} / \mathrm{L}$, and was lower than the healthy control group $0.42(0.25-0.58) \times 10^{9} /$ L (Table 2, Fig. 2a, Fig. 2b). The difference was statistically significant $(\mathrm{Z}=-2.817, \quad \mathrm{P}<0.05)$. The absolute value of $\mathrm{CD}^{-}{ }^{-} \mathrm{CD} 56^{\mathrm{dim}} \mathrm{CD} 16^{\text {bright }} \mathrm{NK}$ cells in the MPP group was $0.26(0.13-0.36) \times 10^{9} / \mathrm{L}$, and was significantly lower than the healthy control group $0.46(0.26-0.58) \times 10^{9} / \mathrm{L}$ 
$(\mathrm{Z}=-3.248, \mathrm{P}<0.05$; Table 2, Fig. 2a, Fig. 2b).

Distribution of NK cell subsets in peripheral blood of children with Mycoplasma pneumoniae pneumonia and allergic constitutions

The percentage of $\mathrm{CD}^{-} \mathrm{CD} 56^{\text {dim }} \mathrm{CD} 16^{\text {bright }} \mathrm{NK}$ cells from the peripheral blood of patients in the allergic group was $7.37 \pm 4.36 \%$, compared with the non-allergic group $11.51 \pm 7.06 \%$. The difference was statistically significant $(\mathrm{t}=2.527, \mathrm{P}<0.05)$. The absolute value of $\mathrm{CD}^{-} \mathrm{CD} 56^{\mathrm{dim}} \mathrm{CD} 16^{\text {bright }} \mathrm{NK}$ cells in the peripheral blood patients with an allergic constitution was $0.19(0.09-0.29) \times 10^{9} / \mathrm{L}$, compared with patients with a non-allergic constitution $0.32(0.22-0.48) \times 10^{9} / \mathrm{L}$, and the difference was statistically significant $(Z=-2.374, \mathrm{P}<0.05)$. The percentage of $\mathrm{CD}^{-} \mathrm{CD}^{-} 6^{+} \mathrm{NK}$ cells of patients with an allergic constitution was $7.74 \pm 4.44 \%$, compared with patients with a non-allergic constitution group $(12.04 \pm 7.33 \%)$. The difference was statistically significant $(\mathrm{t}=2.547, \mathrm{P}<0.05)$. The experimental results are shown in Table 3 and Figures $3 \mathrm{a}, 3 \mathrm{~b}$ and $3 \mathrm{c}$.

Levels of IL-18 and IL-1 $\alpha$ in the peripheral blood of children with Mycoplasma pneumoniae pneumonia

The mean value of IL-18 was $116.21 \mathrm{pg} / \mathrm{ml}$ in the children with MPP compared with $46.24 \mathrm{pg} / \mathrm{ml}$ in the healthy controls $(\mathrm{P}<0.05)$. The mean value of IL-1 $\alpha$ in the MPP group was $3.55 \mathrm{pg} / \mathrm{ml}$ compared with $4.03 \mathrm{pg} / \mathrm{ml}$ in the control group $(\mathrm{P}>0.05)$. The experimental results are shown in Tables 4 and Fig. 4.

Levels of IL-18 and IL-1a in the peripheral blood of children with Mycoplasma Pneumoniae pneumonia and allergic constitutions

The mean value of IL-18 was $118.95 \mathrm{pg} / \mathrm{ml}$ in the children with allergic constitution compared with $113.37 \mathrm{pg} / \mathrm{ml}$ in the children with non-allergic constitution. IL- $1 \alpha$ levels were $3.57 \mathrm{pg} / \mathrm{ml}$ in patients of an allergic constitution and $3.45 \mathrm{pg} / \mathrm{ml}$ in patients without an allergic constitution. There was no significant difference between the two groups $(\mathrm{P}>0.05$; Table 5).

\section{Correlation analysis of NK cell subsets with IL-18 and IL-1 $\alpha$}

The absolute value of $\mathrm{CD}^{-} \mathrm{CD} 56^{\mathrm{dim}} \mathrm{CD} 16^{\text {bright }} \mathrm{NK}$ cells in peripheral blood of children with MPP was negatively correlated with the level of IL-18 ( $\mathrm{r}=-0.892$, 
$\mathrm{P}=0.000$ ). The number of other NK cell subsets was not significantly correlated with the levels of IL-18 or IL-1 $\alpha$. The experimental results are shown in Figure 5.

\section{Discussion}

MPP is a common respiratory illness in children, particularly those with allergic constitutions; however, the immunopathogenesis of MPP is unclear. Animal models of MP infection show that the degree of lung injury caused by MP is related to the host immune response, not necessarily direct microbial damage [7]. MP infection can cause chronic lower respiratory tract inflammation by impairing mucociliary clearance and increasing the production of pulmonary mucus [8]. It can also induce the release of pro-inflammatory cytokines associated with chronic pulmonary diseases such as asthma attacks [9]. T cells, B cells, NK cells and cytokines such as IL-2, IL-6, IL-8, IL-5, IL-12, interferon (IFN)- $\gamma$ and tumor necrosis factor (TNF)- $\alpha$ all participate in the immune response to MP [10]. Both innate and adaptive immunity affect the development and prognosis of MPP. Innate immunity is important in the early stage of MP infection and can prevent the growth of MP in the lungs. MP infection can occur in the airway epithelia for several months, which can lead to a decline in lung function and the subsequent development of asthma. Previous studies have shown that children with allergic MPP have more acute asthma attacks than those with non-allergic MPP, suggesting that children with allergic MPP have a higher risk of asthma [11].

NK cells have been studied in animal models of MP infection and MPP patients. NK cells infected with MP can directly inhibit MP colonization in vivo and remove MP from lungs after intravenous infusion [12]. MP infection can also cause serious immune damage and inflammatory cascades, leading to MPP-associated hemophagocytic syndrome (MPP-HPS)[13]. It is thought that the main pathogenesis of MPP-HPS is a decrease or complete lack of NK cell activity, which prevents the elimination of MP in a timely manner. Continuous stimulation leads to the proliferation of lymphocytes and histiocytes and the release of large quantities of cytokines; a cytokine storm, resulting in multiple organ hyperinflammation and tissue 
damage [14]. Early recruitment of NK cells is crucial to limiting MP infection. They release large amounts of IFN- $\gamma$ and granulocyte-macrophage colony stimulating factor (GM-CSF), leading to macrophage activation [15]. Activated macrophages can inhibit the growth of or directly kill MP. This study found that the number of CD3 ${ }^{-} \mathrm{CD}^{2} 6^{+} \mathrm{NK}$ cells in MPP patients was lower than in healthy controls. Possible reasons for the decrease of NK cells in peripheral blood after MP infection include NK cell death after killing target cells infected by MP, MP or its metabolites may act as superantigens to activate NK cells or induce apoptosis, and MP may directly kill NK cells. The percentage of NK cells in peripheral blood of children with allergic MPP was decreased, but the number of NK cells did not decrease, indicating that the total number of lymphocytes increased and the lymphocyte subsets were redistributed.

NK cells can secrete a variety of cytokines and chemokines, which enable NK cells to interact with innate and adaptive immune effectors [16]. Approximately $10 \%$ of NK cells in peripheral blood are $\mathrm{CD} 56^{\text {bright }} \mathrm{CD} 16^{\mathrm{dim}}$ and produce a large number of cytokines and chemokines, which have immunoregulatory effects, but their ability to kill target cells is poor. The other $90 \%$ of $\mathrm{NK}$ cells are $\mathrm{CD} 56^{\mathrm{dim}} \mathrm{CD} 16^{\text {bright }}$ with abundant cytolytic granules to kill target cells [17]. Recent studies have shown that CD56 ${ }^{\text {dim }} \mathrm{CD} 166^{\text {bright }} \mathrm{NK}$ cells can produce IFN- $\gamma$ 2-4 hours after activation, but no cytokines can be detected after 16 hours. Conversely, CD56 $6^{\text {bright }} \mathrm{CD} 16^{\mathrm{dim}} \mathrm{NK}$ cells only released IFN- $\gamma$ at later stages of an immune response ( $>16$ hours)[18]. IFN- $\gamma$ can enhance the function of macrophages and dendritic cells, promote the maturation and migration of dendritic cells to lymph nodes, inhibit the growth of MP, and regulate Th1 polarization to MP infection [19]. Therefore, CD56 ${ }^{\text {dim }} \mathrm{CD} 16^{\text {bright }} \mathrm{NK}$ cells have cytolytic activity, but can also produce IFN- $\gamma$ early in an immune response enabling them to regulate the immune response. This study found that the percentage of $\mathrm{CD}^{-} \mathrm{CD}^{-} 6^{+} \mathrm{NK}$ cells, $\mathrm{CD}^{-} \mathrm{CD} 56^{\mathrm{dim}} \mathrm{CD} 16^{\text {bright }} \mathrm{NK}$ cells and the number of $\mathrm{CD}^{-}{ }^{-} \mathrm{CD} 56^{\text {bright }} \mathrm{CD} 16^{\text {dim }} \mathrm{NK}$ cells in allergic MPP children were lower than in non-allergic MPP children; however, there was no significant difference in the percentage and number of $\mathrm{CD}^{-} \mathrm{CD}^{-} 6^{\text {bright }} \mathrm{CD} 16^{\mathrm{dim}} \mathrm{NK}$ cells. An imbalance in the NK cell subsets, seen by the decreased $\mathrm{CD}^{-}{ }^{-} \mathrm{CD} 56^{+} \mathrm{NK}$ cells, likely slowed the 
elimination of MP; however, a persistent immune response and the continuous release of cytokines and chemokines may have led to airway hyperresponsiveness and lung function decline. Future research needs to verify the role of cytokines in MPP.

The possible reasons for the decrease in $\mathrm{CD} 56^{\mathrm{dim}} \mathrm{CD} 16^{\text {bright }} \mathrm{NK}$ cells in peripheral blood of children with allergic MPP include that NK cells could have been redistributed to target organs, such as lungs, which reduces the number of circulating NK cells. CD56 ${ }^{\mathrm{dim}} \mathrm{CD} 16^{\text {bright }} \mathrm{NK}$ cells migrate preferentially to the site of acute inflammation [20] and the migration of NK cells to allergic inflammation sites was evident in early studies of allergic asthma[21]. NK cells in bronchoalveolar lavage fluid of severe asthma patients were similar to the CD56 $6^{\text {dim }} \mathrm{CD} 16^{\text {bright }} \mathrm{NK}$ cell population and the level of granzyme A increased significantly. Secondly, the up-regulation of Fas on NK cells in the allergic constitution group may have made the NK cells more prone to apoptosis. Thirdly, cell viability may have been impaired in the allergic children due to chronic inflammation or previous long-term use of antiallergic drugs or glucocorticoids. Glucocorticoids can mediate a decrease in CD56 ${ }^{\text {dim }} \mathrm{CD} 16^{\text {bright }} \mathrm{NK}$ cells and cytotoxic mediators in peripheral blood [22]. Additionally, certain cytokines trigger NK cell death [23]. Lastly, the percentage of NK cells in the allergic constitution group decreased, but the percentage of CD56 $6^{\text {bright }} \mathrm{CD} 16^{\text {dim }} \mathrm{NK}$ cells was not significantly different between the allergic and non-allergic groups; therefore, the percentage of $\mathrm{CD} 56^{\mathrm{dim}} \mathrm{CD} 16^{\text {bright }} \mathrm{NK}$ cells was decreased. Previous studies have shown that $\mathrm{CD} 56^{\text {bright }} \mathrm{CD} 16^{\text {dim }}$ NK cells could differentiate into $\mathrm{CD} 56^{\mathrm{dim}} \mathrm{CD} 16^{\text {bright }} \mathrm{NK}$ cells in the presence of synovial fibroblasts. The decrease in NK cells may be due to fewer CD56 $6^{\text {bright }} \mathrm{CD} 16^{\mathrm{dim}} \mathrm{NK}$ cells differentiating into $\mathrm{CD} 56^{\mathrm{dim}} \mathrm{CD} 16^{\text {bright }} \mathrm{NK}$ cells.

Cytokines can trigger NK cell death; therefore, we compared the level of cytokines in the peripheral blood with the number of NK cells and their subsets in children infected with MP. By measuring the concentration of IL-18 and IL-1 $\alpha$ in peripheral plasma, we speculated that the cytokines may be associated with the decrease in NK cells. In the future, we can focus on the detection of NK cells under the condition of IL-18 knockout MPP. IL-1 is a multifunctional cytokine involved in 
the development of many inflammatory diseases, such as Grave's disease, rheumatoid arthritis, type 2 diabetes mellitus, and chronic hepatitis [24]. The IL-1 cytokine superfamily is composed of 11 members, the most studied are IL-1 $\alpha$, IL-1 $\beta$ and IL-18 [25]. IL-18 is a pro-inflammatory cytokine, mainly produced by goblet cells, and monocytes/macrophages. It has many biological effects, including enhancing Th1 immune responses, inducing $\mathrm{T}$ cells and NK cells to produce IFN- $\gamma$ [23], and promoting NK cell lysis.

The immunological pathogenesis of MPP involves many cytokines [26], and our results suggest that IL-18 is involved. IL-18 has many diverse functions including the induction of GM-CSF and up-regulation of intercellular adhesion molecule-1 in monocytes. IL-18 can also induce delayed-type hypersensitivity (DTH) in vivo. DTH responses to MP may be related to the severity of pneumonia, suggesting that IL-18 could directly affect the respiratory immune response induced by MP, IL-18 can also induce activated $\mathrm{T}$ cell proliferation and NK cell activation [27]. In this study, the expression of IL-18 and IL-1 $\alpha$ in peripheral blood was significantly higher in the MPP patients than in the healthy controls, consistent with a previous report [28]. We found that the serum level of IL-18 was negatively correlated with the absolute value of $\mathrm{CD}^{-}{ }^{-} \mathrm{CD} 56^{\text {dim }} \mathrm{CD} 16^{\text {bright }} \mathrm{NK}$ cells in the peripheral blood of children with an allergic constitution after MP infection, suggesting that this cytokine may have a role in mediating the death of $\mathrm{CD}^{-} \mathrm{CD} 56^{\mathrm{dim}} \mathrm{CD} 16^{\text {bright }} \mathrm{NK}$ cells. However, further mechanistic studies are needed to determine the interplay between IL-18 and NK cell viability.

The percentage of $\mathrm{CD}^{-} \mathrm{CD} 56^{+} \mathrm{NK}$ cells, $\mathrm{CD} 3^{-} \mathrm{CD} 56^{\mathrm{dim}} \mathrm{CD} 16^{\text {bright }} \mathrm{NK}$ cells and the number of $\mathrm{CD} 3^{-} \mathrm{CD} 56^{\mathrm{dim}} \mathrm{CD} 16^{\text {bright }} \mathrm{NK}$ cells were decreased in MPP patients with an allergic constitution. In the allergic constitution group, NK cells with reported cytotoxic activity were reduced in number. Children with poorly responding MPP can be given early gamma globulin support therapy, hormones, or anti-inflammatories, which may alleviate the inflammation. The expression of IL-18 in children with MPP increased significantly, suggesting that IL-18 plays a role in the pathogenesis of acute respiratory MP infection. The absolute value of $\mathrm{CD} 3^{-} \mathrm{CD} 56^{\mathrm{dim}} \mathrm{CD} 16^{\text {bright }} \mathrm{NK}$ cells was 
negatively correlated with the level of IL-18.

\section{Conclusion}

Children with MPP, particularly those with an allergic constitution, were shown to have decreased NK cells in the peripheral blood. IL-18 was concomitantly increased during MPP and may be related to the death of $\mathrm{CD} 3^{-} \mathrm{CD} 56^{\mathrm{dim}} \mathrm{CD} 16^{\text {bright }} \mathrm{NK}$ cells. Understanding the immunopathogenesis of MPP, particularly those with an allergic constitution, will enable the development of new treatment modalities for MPP.

\section{Acknowledgments}

We gratefully acknowledge the cooperation of Mrs. Anwei Xie and her team for collecting peripheral blood and we thank Katie Oakley, $\mathrm{PhD}$, and $\mathrm{S}$. Win, $\mathrm{PhD}$, from Liwen Bianji, Edanz Editing China (www.liwenbianji.cn/ac) for editing the English text of a draft of this manuscript.

\section{Authors' contributions}

Zhang Dandan and Cao Xiuling performed experiments and wrote the manuscript. Li Yuqin, Ding Ying and Yan Li performed experiments. Yu Yixue and Fan Yujie collected clinical specimens and data. Chu Chu conceived the study, participated in its design. Zhou Weifang conceived the study, participated in its design and coordination and wrote the manuscript.

\section{Funding}

This work was supported by the National Natural Science Foundation of China (Yan Li,grant No. 81701948) and the Program of Science and Technology Plan of Suzhou (Weifang Zhou, grant No. SS201535).

\section{Availability of data and materials}

The datasets generated during and/or analyzed during the current study are available 
from the corresponding author on reasonable request.

\section{Ethics approval and consent to participate}

All procedures performed in studies involving human participants were in accordance with the ethical standards of the Institutional Review Board of Children's Hospital of Soochow University (project approval number 2012LW002) and with the 1964 Helsinki declaration and its later amendments or comparable ethical standards. Consent was provided by the parents or legal representatives of patients aged $<16$ years and informed consent forms were archived.

\section{Consent for publication}

All authors have read and approved the content, and they agree to submit it for consideration for publication in the journal.

\section{Competing interests}

The authors declare that they have no competing interests.

\section{Author details}

${ }^{1}$ Department of General Medicine, Children's Hospital of Soochow University, Soochow University, Suzhou, 215003, China.

${ }^{2}$ Department of Infectious Disease, Children's Hospital of Soochow University, Soochow University, Suzhou, 215003, China.

\section{References}

[1]Xiao L, Gu ZB, Liu P,Wang ZQ, Zhang HT. Clinical characteristics of Mycoplasma pneumoniae infection in atopic constitution children and serum IL-17 level. Chinese Journal of Nosocomiology, 2018, 28 (2): 269-272.

[2]Kurai D, Nakagaki K, Wada H, Saraya T, Kamiya S, Fujioka Y, et al. Mycoplasma 
pneumoniae extract induces an IL-17-associated inflammatory reaction in murine lung: implication for mycoplasmal pneumonia. Inflammation, 2013, 36(2):285-93.

[3]Gianchecchi E, Delfino DV, Fierabracci A. NK cells in autoimmune diseases: Linking innate and adaptive immune responses. Autoimmun Rev, 2018, 17(2):242-54.

[4]Respiratory Group, Pediatric Society, Chinese Medical Association, Chinese Medical Association. Guidelines for the Management of Community Acquired Pneumonia in Children (Revised in 2013) (I). Chinese Journal of Pediatrics, 2013, 51 (10): 745-752.

[5]Respiratory Group, Pediatric Society, Chinese Medical Association. Guidelines for the Management of Community Acquired Pneumonia in Children (Revised in 2013) (Part II) . Chinese Journal of Pediatrics, 2013, 51 (11): 856-862.

[6] Feng JY, Chen ZM. The effect of allergic state on serum IL-4,IL-5 and IFN- $\gamma$ after MP infection .Chinese Pediatric Emergency Medicine, 2012, 19(3): 241-244.

[7]Waites KB, Talkington DF. Mycoplasma pneumoniae and its role as a human pathogen. Clin Microbiol Rev, 2004, 17(4):697-728.

[8]Kraft M, Cassell GH, Henson JE, Kraft M, Cassell GH, Henson JE, et al. Detection of Mycoplasma pneumoniae in the airways of adults with chronic asthma. Am J Respir Crit Care Med, 1998, 158(3):998-1001.

[9]Biscardi S, Lorrot M, Marc E, Moulin F, Boutonnat-Faucher B, Heilbronner C,et al. Mycoplasma pneumoniae and Asthma in Children. Clin Infect Dis, 2004, 38(10):1341-6.

[10]Esposito S, Droghetti R, Bosis S, Claut L, Marchisio P, Principi N. Cytokine secretion in children with acute Mycoplasma pneumoniae infection and wheeze. Pediatr Pulmonol, 2002, 34(2):122-7.

[11]Wang ZH, Li XM, Wang YS, Guo ZY. Changes in the Levels of Interleukin-17 Between Atopic and Non-atopic Children with Mycoplasma pneumoniae, Pneumonia. Inflammation, 2016, 39(6):1871-5.

[12]Lai WC, Bennett M, Pakes SP, Kumar V, Steutermann D, Owusu I, et al. 
Resistance to Mycoplasma pulmonis Mediated by Activated Natural Killer Cells. J Infect Dis, 1990, 161(6):1269-75.

[13]Lu ZW, Yang J, Wang Y, He YX, Bai DM, Ma HL, et al. Three cases of Mycoplasma pneumoniae-associated hemophagocytic syndrome and literature review .Chinese Journal of Pediatrics, 2014, 52 (10): 792-796.

[14]Hematology Group, Society of Pediatrics, Chinese Medical Association. Recommendations for diagnosis and treatment of hemophagocytic lymphohistiocytosis . Chinese Journal of Pediatrics, 2012, 50 (11): 821-825.

[15]Muller K, van Zandbergen G, Hansen B, Laufs H, Jahnke N, Solbach W,et al. Chemokines, natural killer cells and granulocytes in the early course of Leishmania major infection in mice. Med Microbiol Immunol, 2001, 190(1-2):73-6.

[16]Vivier E, Raulet DH, Moretta A, Caligiuri MA, Zitvogel L, Lanier LL, et al. Innate or Adaptive Immunity? The Example of Natural Killer Cells[J]. Science, 2011, 331(6013):44-9.

[17]Le Garff- Tavernier M, Decocq J, De Romeuf C, Parizot C, Dutertre C A, Chapiro E, et al. Analysis of $\mathrm{CD} 16^{+} \mathrm{CD} 56^{\mathrm{dim}} \mathrm{NK}$ cells from CLL patients: evidence supporting a therapeutic strategy with optimized anti-CD20 monoclonal antibodies. Leukemia, 2011, 25(1):101-9.

[18]De Maria A, Bozzano F, Cantoni C, Moretta L. Revisiting human natural killer cell subset function revealed cytolytic CD56(dim)CD16 + NK cells as rapid producers of abundant IFN-gamma on activation. Proc Natl Acad Sci U S A, 2011, 108(2):728-32.

[19]Huang H, Zhong L L, Peng L, Li J, Lin L. Levels of interleukin-4 and interferon-gamma in the bronchoalveolar lavage fluid of children with refractory Mycoplasma pneumoniae pneumonia. Zhongguo Dang Dai Ee Ke Za Zhi, 2012, 14(8):581-4.

[20]von Bubnoff D, Andrès E, Hentges F, Bieber T, Michel T, Zimmer J. Natural killer cells in atopic and autoimmune diseases of the skin. J Allergy Clin Immunol, 2010, 125(1):60-68.

[21]Schuster M, Tschernig T, Krug N, Pabst R. Lymphocytes migrate from the blood into the bronchoalveolar lavage and lung parenchyma in the asthma model of the 
brown Norway rat. Am J Respir Crit Care Med, 2000, 161(2 Pt 1):558-66.

[22]Hiebert PR, Granville DJ. Granzyme B in injury, inflammation, and repair. Trends Mol Med, 2012, 18(12):732-41.

[23]Shibatomi K, Ida H, Yamasaki S, Nakashima T, Origuchi T, Kawakami A, et al. A novel role for interleukin-18 in human natural killer cell death: high serum levels and low natural killer cell numbers in patients with systemic autoimmune diseases. Arthritis Rheum, 2001, 44(4):884-92.

[24]Dinarello CA. Biologic basis for interleukin-1 in disease. Blood, 1996, 87(6):2095-147.

[25]Fang R, Wu R, Du H, Jin M, Liu Y, Lei G, et al. Pneumolysin-dependent calpain activation and IL-1 secretion in macrophages infected with Streptococcus pneumoniae. Infect Immun, 2017, 85(9):201-17.

[26]Hanzawa F, Fuchigami T, Ishii W, Nakajima S, Kawamura Y, Endo A, et al. A 3-year-old boy with Guillain-Barré syndrome and encephalitis associated with Mycoplasma pneumoniae infection. J Infect Chemother, 2014, 20(2):134-8.

[27]Tanaka H, Narita M, Teramoto S, Saikai T, Oashi K, Igarashi T, et al. Role of interleukin-18 and T-helper type 1 cytokines in the development of Mycoplasma pneumoniae pneumonia in adults. Chest, 2002, 121(5):1493-7.

[28]Oishi T, Narita M, Kou M, Shirai T, Matsuo M, Negishi J.et al. Clinical implications of interleukin-18 levels in pediatric patients with Mycoplasma pneumoniae, pneumonia. J Infect Chemother, 2011, 17(6):803-6.

Tables

Table 1 Age and sex distribution of the children

\begin{tabular}{lll}
\hline Situation & Sex $($ male/female $)$ & Age \\
\hline MPP(n=51) & $25 / 26$ & $3.34 \pm 2.28$ \\
Control(n=29) & $16 / 13$ & $3.29 \pm 2.17$ \\
Statistics & $\chi^{2}=0.280$ & $\mathrm{t}=-0.110$ \\
Allergic $(\mathrm{n}=26)$ & $13 / 13$ & $3.26 \pm 2.19$ \\
Non-allergic $(\mathrm{n}=25)$ & $12 / 13$ & $3.43 \pm 2.40$ \\
Statistics & $\chi^{2}=0.020$ & $\mathrm{t}=0.259$ \\
\hline
\end{tabular}


Note: ${ }^{*} \mathrm{p}<0.05 ; * * \mathrm{p}<0.01$.

Table 2 Distribution of NK cell subsets in peripheral blood of children with MPP or healthy controls

\begin{tabular}{lllll}
\hline & MPP & Control & Statistics & $p$ value \\
\hline $\mathrm{CD}^{-}{ }^{-} \mathrm{CD} 56^{\text {bright }} \mathrm{CD} 16^{\mathrm{dim}}(\%)$ & $0.25(0.14-0.45)$ & $0.22(0.14-0.41)$ & $\mathrm{Z}=-0.706$ & 0.480 \\
$\mathrm{CD} 3^{-} \mathrm{CD} 56^{\text {bright }} \mathrm{CD} 16^{\mathrm{dim}}\left(\times 10^{6} /\right.$ & $7.98(3.83-15.60)$ & $7.97(5.61-16.74)$ & $\mathrm{Z}=-0.035$ & 0.972 \\
$\mathrm{CD} 3^{-} \mathrm{CD} 56^{\mathrm{dim}} \mathrm{CD} 16^{\text {bright }}(\%)$ & $9.40 \pm 6.14$ & $10.46 \pm 5.41$ & $\mathrm{t}=0.731$ & 0.467 \\
$\mathrm{CD} 3^{-} \mathrm{CD} 56^{\mathrm{dim}} \mathrm{CD} 16^{\text {bright }}\left(\times 10^{9} /\right.$ & $0.26(0.13-0.36)$ & $0.46(0.26-0.58)$ & $\mathrm{Z}=-3.248^{* *}$ & 0.001 \\
$\mathrm{CD} 3^{-} \mathrm{CD} 56^{+}(\%)$ & $9.85 \pm 6.35$ & $10.65 \pm 5.47$ & $\mathrm{t}=0.575$ & 0.567 \\
$\mathrm{CD} 3^{-} \mathrm{CD} 56^{+}\left(\times 10^{9} / \mathrm{L}\right)$ & $0.27(0.14-0.40)$ & $0.42(0.25-0.58)$ & $\mathrm{Z}=-2.817^{* *}$ & 0.005 \\
\hline
\end{tabular}

Note: ${ }^{*} \mathrm{p}<0.05 ;{ }^{* *} \mathrm{p}<0.01$.

Table 3 Distribution of NK cells and their subsets in peripheral blood of children with allergic and non-allergic constitutions

\begin{tabular}{lllll}
\hline & Allergic & Non-allergic & Statistics & $\mathrm{P}$ \\
\hline $\mathrm{CD} 3^{-} \mathrm{CD} 56^{\text {bright }} \mathrm{CD} 16^{\mathrm{dim}}(\%)$ & $0.23(0.14-0.41)$ & $0.25(0.13-0.55)$ & $\mathrm{Z}=-0.509$ & 0.611 \\
$\mathrm{CD} 3^{-} \mathrm{CD} 56^{\text {bright }} \mathrm{CD} 16^{\mathrm{dim}}\left(\times 10^{6} /\right.$ & $6.74(3.63-15.15)$ & $11.17(4.29-18.27$ & $\mathrm{Z}=-0.829$ & 0.407 \\
$\mathrm{CD}{ }^{-} \mathrm{CD} 56^{\mathrm{dim}} \mathrm{CD} 16^{\text {bright }}(\%)$ & $7.37 \pm 4.36$ & $11.51 \pm 7.06$ & $\mathrm{t}=2.527 * *$ & 0.015 \\
$\mathrm{CD}{ }^{-} \mathrm{CD} 56^{\mathrm{dim}} \mathrm{CD} 16^{\text {bright }} \times 10^{9} /$ & $0.19(0.09-0.29)$ & $0.32(0.22-0.48)$ & $\mathrm{Z}=-2.374 *$ & 0.018 \\
$\mathrm{CD} 3^{-} \mathrm{CD} 56^{+}(\%)$ & $7.74 \pm 4.44$ & $12.04 \pm 7.33$ & $\mathrm{t}=2.547 *$ & 0.014 \\
$\mathrm{CD} 3^{-} \mathrm{CD} 56^{+}\left(\times 10^{9} / \mathrm{L}\right)$ & $0.26 \pm 0.22$ & $0.36 \pm 0.22$ & $\mathrm{t}=1.613$ & 0.113 \\
\hline
\end{tabular}

Note: ${ }^{*} \mathrm{p}<0.05 ;{ }^{* *} \mathrm{p}<0.01$.

Table 4 Comparison of IL-18 and IL-1 $\alpha$ between MPP group and healthy control group

\begin{tabular}{lllll}
\hline & MPP & Control & Statistics & $\mathrm{p}$ value \\
\hline $\mathrm{IL}-18(\mathrm{pg} / \mathrm{ml})$ & $116.21 \pm 45.96$ & $46.24 \pm 25.02$ & $\mathrm{t}=-7.570^{* *}$ & 0.000 \\
$\mathrm{IL}-1 \alpha(\mathrm{pg} / \mathrm{ml})$ & $3.55 \pm 2.43$ & $4.03 \pm 2.68$ & $\mathrm{t}=0.831$ & 0.408 \\
\hline
\end{tabular}

Note: ${ }^{*} \mathrm{p}<0.05 ;{ }^{* *} \mathrm{p}<0.01$. 
Table 5 Comparison of IL- 18 and IL- $1 \alpha$ between allergic and non-allergic children

\begin{tabular}{lllll}
\hline & Allergic & Non-allergic & Statistics & p value \\
\hline IL-18 $(\mathrm{pg} / \mathrm{ml})$ & $118.95 \pm 49.04$ & $113.37 \pm 43.35$ & $\mathrm{t}=-0.430$ & 0.669 \\
$\mathrm{IL}-1 \alpha(\mathrm{pg} / \mathrm{ml})$ & $3.57 \pm 2.43$ & $3.45 \pm 2.50$ & $\mathrm{t}=-0.167$ & 0.868 \\
\hline
\end{tabular}

Note: ${ }^{*} \mathrm{p}<0.05 ;{ }^{*} \mathrm{p}<0.01$.

Figure Legends

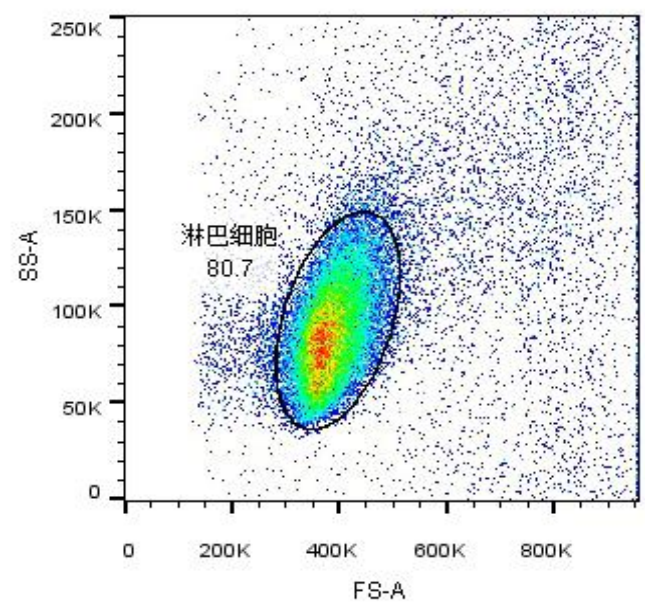

Fig. 1A, SS and FS scattered light signals

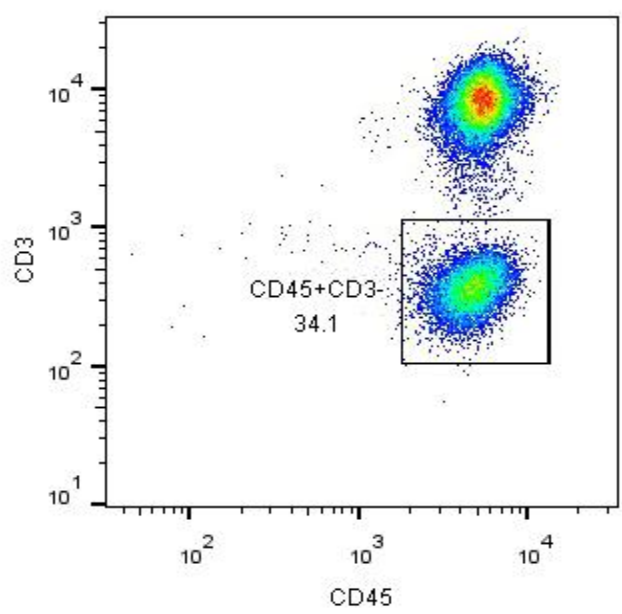

Fig. 1B, CD45+CD3- cells

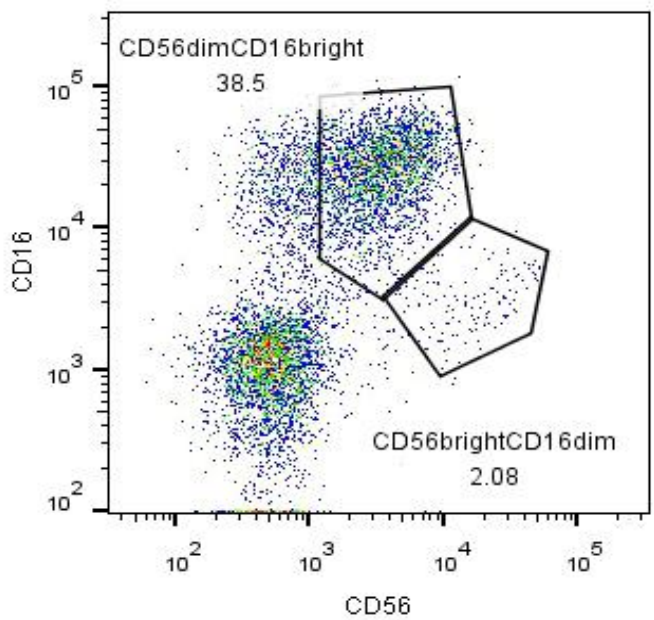

Fig. 1C. Flow cytometric identification of NK cell subsets 


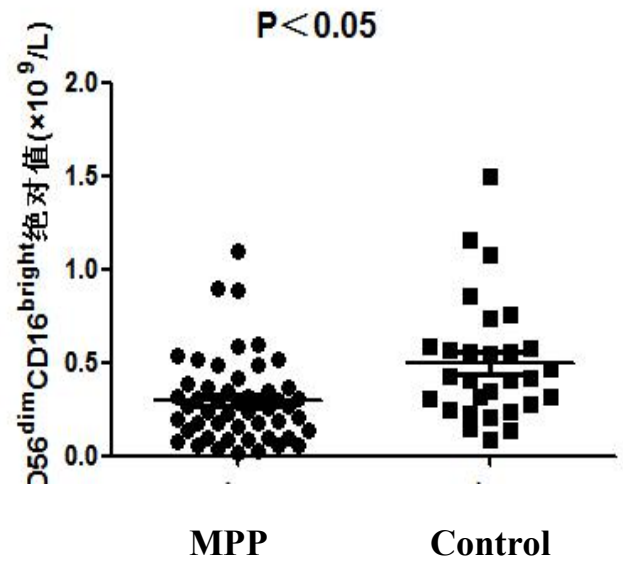

Fig. 2a CD56 ${ }^{\mathrm{dim}} \mathrm{CD} 16^{\text {bright }} \mathrm{NK}$ cells from peripheral blood of patients with MPP and control group

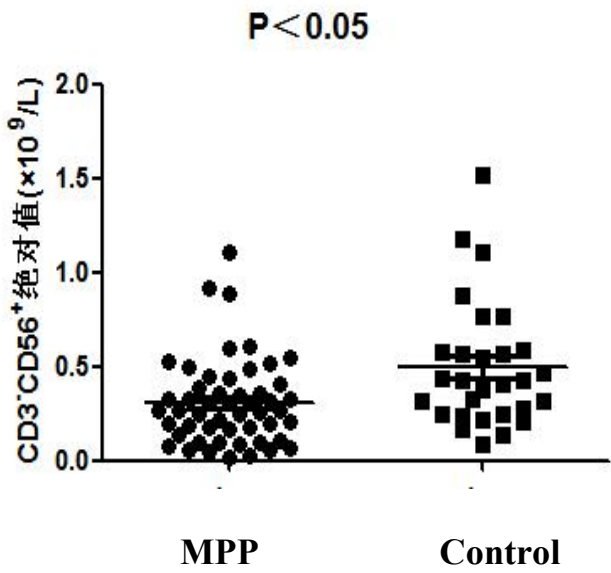

Fig. $2 \mathrm{~b}$ The absolute value of $\mathrm{CD} 3^{-} \mathrm{CD} 56^{+} \mathrm{NK}$ cells in peripheral blood from the MPP group and healthy control group

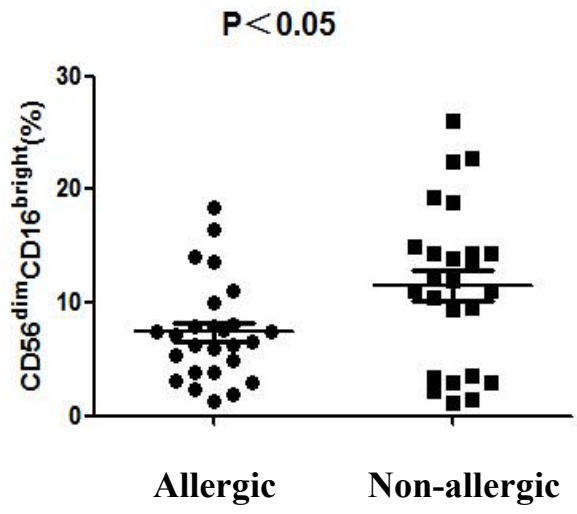

Fig. 3a The CD56 ${ }^{\text {dim }}$ CD16 ${ }^{\text {bright }}$ NK cell ratio in the allergic group and non-allergic group 


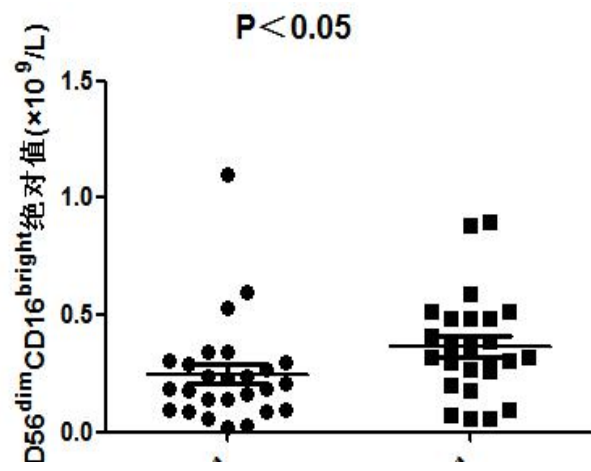

Allergic Non-allergic

Fig. $3 \mathrm{~b}$ Absolute values of CD56 ${ }^{\mathrm{dim}} \mathrm{CD} 16^{\text {brigh }} \mathrm{NK}$ cells in the allergic and non-allergic groups $P<0.05$

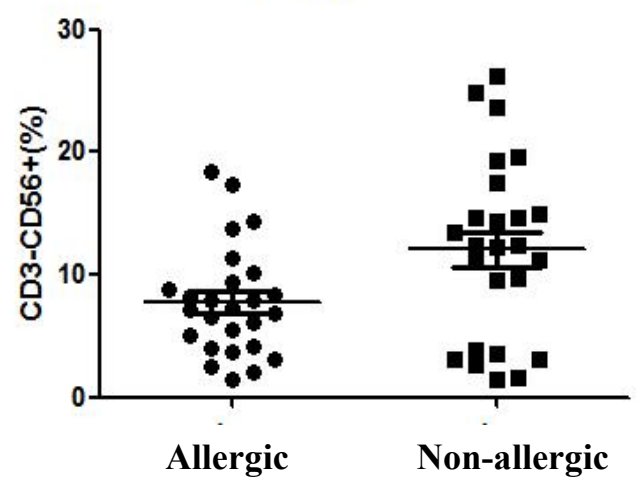

Fig. $3 \mathrm{c} \mathrm{CD} 3^{-} \mathrm{CD}^{2} 6^{+} \mathrm{NK}$ cell ratios in the allergic and non-allergic groups

$$
\mathbf{P}<0.05
$$

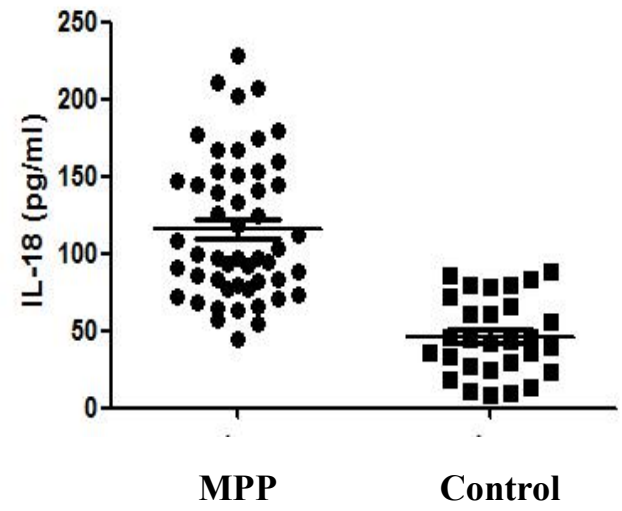

Fig. 4 IL-18 levels in the peripheral blood of the MPP group and control group 
$r=-0.892, P<0.001$

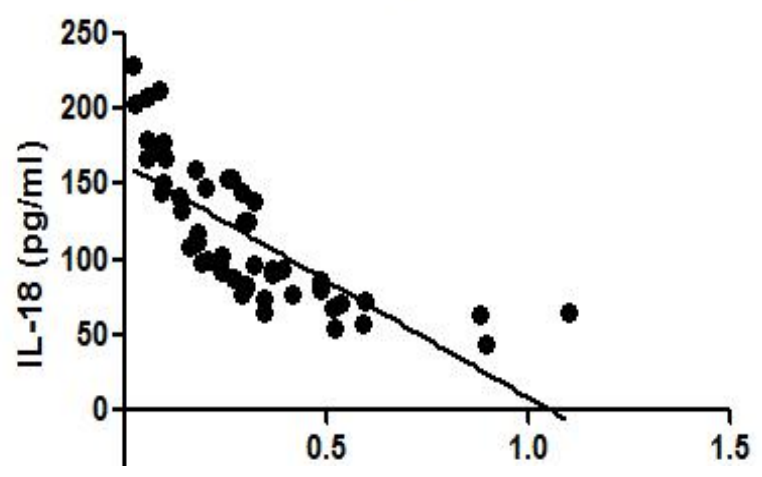

Absolute value of CD56 ${ }^{\text {dim }}$ CD16 $6^{\text {bright }} \mathrm{NK}$ cells(x109/L)

Fig. 5 The correlation between the absolute value of CD56 ${ }^{\mathrm{dim}} \mathrm{CD} 16^{\text {bright }} \mathrm{NK}$ cells and IL-18 in the peripheral blood of children with MPP 